\title{
Síndrome da alienação parental: um novo tema nos juízos de família
}

\author{
Marcele T. Homrich Ravasio* \\ Universidade Federal do Rio Grande do Sul - UFRGS, Porto Alegre, Rio Grande do \\ Sul, Brasil
}

SOUZA, A. M. de. Síndrome da alienação parental: um novo tema nos juízos de família. São Paulo: Cortez, 2010.

A lei $n^{\circ}$ 12.318, aprovada em 26 de agosto de 2010, apresenta os elementos norteadores e definidores da Síndrome da Alienação Parental. Entre as pesquisas e publicações dedicadas ao tema, merece destaque o livro de Analice Martins de Souza, resultado de sua dissertação de mestrado pelo programa de pós-graduação em psicologia social da Universidade do Estado do Rio de Janeiro.

A pesquisa toma como base a pergunta: o que a Síndrome da Alienação Parental estaria encobrindo? Seu embasamento teórico é conduzido pela perspectiva foucaultiana, pelo qual se compreende que as práticas sociais produzem certos saberes e poderes, assim como fazem surgir novos conceitos e objetos. De maneira perspicaz a autora analisa e debate o tema a partir de uma posição questionadora, partindo do diálogo com autores que têm se debruçado sobre o assunto, aliada a crítica que a análise sóciohistórica acerca dos papéis parentais e das relações de gênero possibilita.

Na primeira parte dessa obra, de maneira sistemática e detalhada, são apresentados os elementos conflituosos presentes no rompimento conjugal, conceituando e distinguindo categorias como parentalidade e conjugalidade. A autora desenvolve sua reflexão a partir de várias pesquisas realizadas sobre o assunto nos últimos anos. Parentalidade e conjugalidade são consideradas categorias densas, sendo que há uma influência mútua entre elas no estabelecimento dos vínculos familiares, produzindo conflitos dos mais diversos. A autora considera que na atualidade há uma tendência a ignorar tais elementos constitutivos das relações, em decorrência da sobreposição a lógica de consumo, que atravessa o momento sócio-histórico em que os atores estão inseridos.

Assim, as relações amorosas e os sentimentos são espécies de sensações a serem consumidas de modo fugaz e instantâneo, visando - prazer e satisfação momentânea. Também são discutidos elementos acerca do trabalho dos psicólogos jurídicos, a avaliação 
psicológica e a insuficiência das redes sociais de apoio as famílias frente à necessidade de acompanhamento as mudanças familiares pós-divórcio.

Discursos médicos, políticos e econômicos são analisados no segundo capítulo, focando a formação social dos papéis parentais, sendo que estes associam a função de cuidar e educar os filhos à figura da mãe. Além de uma revisão de literatura sobre o primado materno, a autora faz um percurso na sua escrita que possibilita a compreensão e análise de como esses discursos permanecem correntes nos dias atuais, fazendo parte do "tornar-se homem ou mulher" na atualidade. Na mesma perspectiva a mídia, as instituições sociais, assim como mudanças ocorridas na legislação, convergem no sentido de disseminar a disparidade de tratamento entre os papéis de pai e mãe. Neste capítulo a autora focaliza a sua análise sócio-histórica acerca dos papéis parentais.

Num terceiro momento da obra, apresentam-se as questões metodológicas da pesquisa, detalhando os procedimentos de análise dos textos de Richard Gardner, assim como outros autores que abordam o assunto. A autora também apresenta como acompanhou os meios de divulgação em torno do assunto no Brasil, assim com a utilização do método de análise dos textos, para compreensão, interpretação e discussão das publicações.

$\mathrm{Na}$ quarta parte do livro, intitulado A síndrome da alienação parental e outras perspectivas, é realizada a apresentação das proposições de Richard Gardner, precursor da discussão. Nesse viés são apontadas as críticas e questionamentos advindos após a propagação da idéia de Gardner, assim como autores, publicações e movimentos sociais que contribuíram na disseminação de uma posição questionadora sobre a SAP.

No último capítulo, nomeado Discursos sobre a síndrome da alienação parental do Brasil, a autora analisa a partir das categorias que emergiram em textos publicados no Brasil, que há uma tendência a propagação das idéias de Richard Gradner, sem a preocupação de discussões e debates sobre o tema. Entre as cinco categorias emergentes encontramos: 1) as definições e indefinições apresentadas pelos autores que se dedicam ao tema, logo são 2) explicitadas as justificativas para o desenvolvimento da SAP, oriundas destas estão as 3 ) listas de consequências sobre a vida das vítimas. As duas últimas categorias são 4) os pontos utilizados para realização do diagnóstico, e 5) as punições possíveis para o alienador. Portanto, há um predomínio da escassez de reflexões críticas sobre a SAP.

Para concluir, a autora compreende, em relação a SAP, que há uma tendência para a patologização do comportamento nas sociedades contemporâneas, consequentemente um aumento no número de diagnósticos possíveis. Para tanto a SAP é tratada como uma 
problemática individual, negando-se os elementos sociais, políticos e econômicos que podem ser compreendidos como produtores dos sintomas sociais contemporâneos. Os indivíduos, na perspectiva da SAP, são vistos como a origem e a causa de todos os males, problemáticas e conflitos que apresentam.

Nesta perspectiva, a problemática coletiva é transformada em uma crise pessoal e psiquiátrica. Tal disseminação tornou-se possível, pois as idéias de Gardner foram divulgadas com escassez de críticas e questionamentos no Brasil, na intenção de difundir o tema, deixando de lado a importância da realização de debates e estudos sobre o tema.

A importância dos profissionais que atuam nos juízos de família também são citados nas publicações nacionais como atores de relevância. A autora analisa que a atuação dos psicólogos peritos por meio de avaliações individuais estaria construindo o objeto da SAP, encaixando os conflitos relacionais observados em uma síndrome. Para tanto, estes profissionais necessitariam uma posição crítica e reflexiva frente às exigências advindas de tais instituições sociais.

A obra apresentada é de suma importância frente a esta demanda social de patologização e produção de diagnóstico. Cabe pensar o papel do psicólogo em face das necessidades sociais que escondem um sintoma social contemporâneo, que não é de ordem individual, mas sim uma produção coletiva, que poderia dar voz a elementos sócio-históricos, produzidos e produtores de sujeitos imersos na lógica contemporânea.

É fundamental pensar acerca do surgimento de comportamentos ditos individuais, para que assim se possa ler e intervir sobre os diferentes elementos sociais, jurídicos, políticos e legislativos. Esta prática estaria no viés de possibilitar/transformar elementos sociais estagnados e reproduzidos de maneira alienante.

\section{Endereço para correspondência \\ Marcele T. Homrich Ravasio}

Rua Marquês Tamandaré, 712, apt 401, Cep 98802540 - Santo Ângelo, RS

Endereço eletrônico: celehomrich@ibest.com.br

Recebido em: 08/06/2011

Aceito para publicação em: 19/04/2012

Acompanhamento do processo editorial: Alexandra Cleopatre Tsallis

\section{Notas}

* Doutoranda Educação pela Universidade Federal do Rio Grande do Sul - UFRGS. Docente do Instituto Cenecista de Ensino Superior de Santo Ângelo. Membro da Associação Espaço Psicanalítico - AEP - Ijuí/RS. 